\title{
Multidisciplinary intervention in obese adolescents: predictors of dropout
}

\author{
Intervenção multidisciplinar em adolescentes obesos: preditores de desistência
}

\author{
Yara Lucy Fidelix ${ }^{1}$, José Cazuza de Farias Júnior ${ }^{2}$, Mara Cristina Lofrano-Prado ${ }^{3}$, \\ Ricardo Luís Fernandes Guerra ${ }^{4}$, Michelle Cardel $^{5}$, Wagner Luiz do Prado ${ }^{6}$
}

\begin{abstract}
Objective: To identify biological and psychosocial factors associated with dropout in a multidisciplinary behavioral intervention in obese adolescents. Methods: A total of 183 adolescents (15.4 \pm 1.6 years), pubertal (Tanner stage 3 or 4 ) and obese $\left(34.7 \pm 4.0 \mathrm{~kg} / \mathrm{m}^{2}\right)$, were enrolled in a 12-week behavioral intervention, which included clinical consultations (monthly), nutritional and psychological counseling (once a week), and supervised aerobic training (three times/week). The studied variables were weight, height, body mass index, body composition (skinfold), cardiorespiratory fitness (direct gas analysis), blood lipids and self-reported symptoms of eating disorders (bulimia, anorexia and binge eating), anxiety, depression, body image dissatisfaction and quality of life. Statistical analysis included binary logistic regression and independent $t$-tests. Results: Of the adolescents, $73.7 \%$ adhered to the program. The greatest chance for dropout was observed among adolescents older than 15 years (odds ratio of $0.40 ; 95 \% \mathrm{Cl}: 0.15-0.98$ ), with more anorexia symptoms (odds ratio of $0.35 ; 95 \% \mathrm{Cl}: 0.14-0.86$ ) and hypercholesterolemia (odds ratio of $0.40 ; 95 \% \mathrm{Cl}: 0.16-0.91$ ) at baseline. Conclusion: Older adolescents, with more symptoms of eating disorders and total cholesterol have less chance to adhere to multidisciplinary treatments.
\end{abstract}

Keywords: Patient dropouts; Adiposity; Lipids; Quality of life; Eating disorders; Adolescent

\section{RESUMO}

Objetivo: Identificar os fatores biológicos e psicossociais associados à desistência de uma intervenção multidisciplinar comportamental em adolescentes obesos. Métodos: Foram selecionados para participar das 12 semanas de intervenção 183 adolescentes (15,4 41,6 anos), púberes (Tanner 3 ou 4$)$ e obesos $\left(34,7 \pm 4,0 \mathrm{~kg} / \mathrm{m}^{2}\right)$. A intervenção incluiu consultas clínicas (mensal), aconselhamento nutricional e psicológico (uma vez/semana), e treinamento aeróbio supervisionado (três vezes/semana). As variáveis estudadas foram peso, altura, índice de massa corporal, composição corporal (dobras cutâneas), aptidão cardiorrespiratória (análise direta de gases), perfil lipídico e sintomas autorrelatados de transtornos alimentares (bulimia, anorexia e compulsão alimentar), ansiedade, depressão, insatisfação com a imagem corporal e qualidade de vida. A análise estatística incluiu regressão logística binária e teste $t$ de Student independente. Resultados: Aderiram ao programa $73,7 \%$ dos adolescentes. A maior chance de desistência foi observada entre aqueles com mais de 15 anos (odds ratio de 0,40; IC95\%: 0,15-0,98), com mais sintomas de anorexia (odds ratio de 0,35; IC95\%: 0,14-0,86) e com hipercolesterolemia (odds ratio de 0,40; IC95\%: 0,16-0,91) no início do estudo. Conclusão: Adolescentes mais velhos, com mais sintomas de transtornos alimentares e de níveis de colesterol total, têm menor chance de aderir a tratamentos multidisciplinares.

Descritores: Pacientes desistentes do tratamento; Adiposidade; Lipídeos; Qualidade de vida; Transtornos da alimentação; Adolescente

\footnotetext{
Universidade de Pernambuco, Recife, PE, Brazil.

2 Universidade Federal da Paraíba, João Pessoa, PB, Brazil.

${ }^{3}$ Universidade Federal de Pernambuco, Recife, PE, Brazil.

${ }^{4}$ Universidade Federal de São Paulo, Santos, SP, Brazil.

${ }^{5}$ University of Colorado, Denver, CO, Estados Unidos.

${ }^{6}$ Universidade Federal de São Paulo, Santos, SP, Brazil; Programa Associado de Pós-Graduação em Educação Física, Universidade de Pernambuco, Recife, PE, Brazil; Universidade Federal da Paraíba, João Pessoa, PB, Brazil.

Corresponding author: Yara Lucy Fidelix - Avenida Getúlio Vargas, 1,360 - Bairro Novo - Zip code: 53030-010 - Olinda, PE, Brazil - Phone: (55 81) $3493-2956$ - E-mail: yarafidelix@hotmail.com

Received on: Feb 18, 2015 - Accepted on: May 21, 2015

Conflict of interest: none.
}

DOI: 10.1590/\$1679-45082015A03339 


\section{INTRODUCTION}

Evidence suggests that long-term multidisciplinary behavioral intervention is the most effective approach to achieve weight loss and health-related goals, ${ }^{(1)}$ and that such interventions are more likely to be effective in children and adolescents than adults. ${ }^{(2)}$

However, the literature indicates a strong relationship between obesity in adolescents and dropout of supervised exercise programs, as well as low rates of success in weight loss programs for overweight/ obese adolescents. ${ }^{(3)}$ Given that adherence has a great influence on weight loss outcomes, ${ }^{(4)}$ these unexpected results may be at least partly attributed to the high dropout observed in obese children and adolescents. ${ }^{(5)}$ On average, $50 \%$ of adults quit before completing therapy, ${ }^{(4)}$ whereas in adolescents the dropout rate is 33 to $45 \% .^{(6,7)}$

Several biological and psychosocial barriers make it difficult to adhere to behavioral interventions. ${ }^{(8)}$ A recent review showed that studies are focusing on the psychological, social and demographic aspects of adherence, but the study of biological factors influencing adherence are limited in the current literature. ${ }^{(9)}$

Given the high obesity prevalence in adolescents worldwide, ${ }^{(10)}$ and the well-known deleterious effects of excessive adiposity on health, increasing the risk for premature death, ${ }^{(11)}$ it is imperative that we study and identify factors related to adherence. ${ }^{(12)}$ Identification of patients at risk of dropout will contribute to both the efficacy and the cost-effectiveness of weight loss interventions. ${ }^{(13)}$

\section{OBJECTIVE}

To identify biological and psychosocial factors associated with dropout in a multidisciplinary behavioral intervention in obese adolescents.

\section{METHODS}

\section{Participants}

Obese adolescents were recruited from the greater metropolitan area of the city of Recife, in Brazil, from 2010 to 2013, through local television, newspaper and radio advertisements. The inclusion criteria were: age 12 to 18 years, pubertal stage ( 3 and 4$),{ }^{(14)}$ and a body mass index $(\mathrm{BMI})>95$ th percentile for sex and age. Participants were excluded if they had a medical condition that restricted them from engaging in a regular exercise program or if they weighed more than $120 \mathrm{~kg}$ (due to equipment limitation). Additional exclusion criteria included pregnancy, presence of hypertension or other metabolic complications (hyperinsulinemia and hypercholesterolaemia) and previous use of weight loss drugs. The study was approved by the Ethics Committee of the Universidade de Pernambuco (154/09), CAAE: 15798113.9.0000.5207 and the parents/ legal guardians signed the Informed Consent Form.

\section{Study design}

A total of 983 adolescents volunteered for the study. During the first visit to the laboratory, pubertal stage, height and weight were measured. In the second visit, the participants performed a rest electrocardiogram, and underwent a medical screening. One hundred eighty-three (183) adolescents met all inclusion criteria and were included in the study. Participants were considered adherent if they participated in at least $75 \%$ of all intervention sessions. ${ }^{(15)}$ All participants received the same multidisciplinary behavioral intervention, as described below.

\section{Multidisciplinary behavioral intervention}

The main goals of the multidisciplinary behavioral intervention were reduction in body weight and promotion of healthy practices and change in lifestyle behaviors. The treatment consisted of clinical, nutritional, psychological and aerobic physical exercise monitoring for 12 weeks, as described elsewhere. ${ }^{(16)}$ The participants were attended by the same researchers in all cohorts (2010 and 2012: August to October; 2011: March to May; 2013: April to June).

\section{Endocrinologist consultation}

Medical follow-up was performed once a month by an endocrinologist. This included a physical examination to monitor clinical parameters and to facilitate overall compliance with the study.

\section{Nutritional intervention}

Nutritional intervention consisted of group meetings (approximately ten adolescents), once a week, lasting 1 hour. The activities were developed and supervised by a nutritionist. During the meetings, some topics such as fast food, nutritional labeling, types of fat, diet and light products, and strategies for special occasions (holidays, birthdays were addressed) were addressed. Participants were not prescribed any individualized diet. 


\section{Psychotherapy}

Psychotherapy was conducted for 1 hour each week in small groups (roughly nine adolescents) by a clinical psychologist. Along with psychological motivation for compliance, the session themes related to body image, eating disorders (symptoms and consequences), the relationship between food and feelings, family and social problems, mood, anxiety and depression were included.

\section{Supervised aerobic exercise training}

Participants performed individualized aerobic training on a treadmill three times a week under the supervision of a physical education professional. The sessions were isocaloric, with energy expenditure fixed at 350kcal/ session. Once the training intensity was individualized, the duration of sessions differed between subjects ( 30 to 60 minutes, approximately).

\section{Assessment}

\section{Anthropometrics and body composition}

Body mass $(\mathrm{kg})$ was determined using scales (Filizola) with accuracy of $0.1 \mathrm{~kg}$ and height was measured using a fixed stadiometer with wooden scale accuracy of $0.1 \mathrm{~cm}$. Thereafter, we calculated BMI by dividing body weight by height squared $\left(\mathrm{kg} / \mathrm{m}^{2}\right)$. The triceps, subscapular and calf skinfolds were measured in the right hemisphere with a caliper Lange ${ }^{\circledR}$ with a resolution of $1 \mathrm{~mm}$. The skinfolds were measured in triplicate by the same evaluator, rotational manner, and after mean value was calculated. All measurements followed the protocol and fat mass percentage $(\% \mathrm{FM})$ was estimated by the equation. ${ }^{(17)}$

\section{Biochemical analyzes}

Sample collection biological material was performed by puncture of peripheral forearm vein after an overnight fast of 12 hours. Blood samples were collected and total cholesterol, high density lipoprotein (HDL), low density lipoprotein (LDL), very low density lipoprotein (VLDL), triglycerides and glucose were determined by immuno-enzymatic assay, using commercial Enzyme Linked Immuno Sorbent Assay (ELISA) kits (Phoenix Pharmaceuticals, Inc. California, United States), following all manufacturer's recommendations.

\section{Cardiorespiratory test}

Cardiorespiratory fitness was determined through direct gas analysis during continuous and incremental test on a treadmill (Cosmed T200, Italy). The equipment was calibrated to the gas mixture and volume before each test. The test protocol consisted of 3-minutes warm-up (4km/hour) and 1-minute test was performed increased by $1 \mathrm{~km} /$ hour, until voluntary exhaustion, or when the Borg scale and the respiratory quotient presented values above 18 and 1.15 , respectively.

\section{Psychological assessments and quality of life}

Adolescents answered questionnaires translated and validated for the Brazilian population. The adolescents were evaluated regarding the presence of eating disorder symptoms (Attitudes Test - EAT-26; Bulimic Investigatory Test Edinburgh - BITE; and Binge Eating Scale - BES), anxiety (State-Trait Anxiety Inventory STAI), depression (Beck Depression Inventory BDI), dissatisfaction with body image (Body Shape Questionnaire - BSQ) and self-rated quality of life (Medical Outcomes Study 36 - Item Short - Form Health Survey - SF-36).

\section{Statistical analysis}

The mean difference between groups (adherence versus non-adherence) was tested by independent Student's $t$ test. Binary logistic regression was used to analyze association between adherence (people who did adhere $=0$ versus people who dropout $=1$ ) and the independent variables were age, height, weight, BMI, body composition (fat mass and fat free mass), biochemical analyzes (total cholesterol, LDL, triglycerides, VLDL, HDL, glucose), peak oxygen uptake consumption (peak $\mathrm{VO}_{2}$ ), anorexic symptoms, trait anxiety, state anxiety, depression, binge, bulimia symptoms, bulimia severity, body dissatisfaction and quality of life, all categorized according to the 50th percentile, except for age ( $<15$ years or $>15$ years), sex (male or female) and training period (morning or afternoon). In the adjusted analysis, the variables with a $\mathrm{p}$ value $<0.20$ for the significance level in the crude analysis were entered into the model and remained in the final model. The a significance level of $\mathrm{p} \leq 0.05$.

\section{RESULTS}

Out of 183 adolescents included in the sample, 134 $(73.2 \%)$ adhered to treatment, with no sex differences (76\% of boys and $71.3 \%$ of girls). Dropout adolescents were older than their adherent counterparts $(p=0.01)$ (Table 1). 
In the crude analysis we observed that age (odds ratio of 0.48; confidence interval 95\% CI: 0.24-0.97) was associated with dropout, showing that adolescents aged $>15$ years had 0.48 less chance to adhere to the program, compared to younger ones (Table 2).

The adjusted analysis (Table 3 ) showed that adolescents aged over 15 years and those above the 50th percentile for scores of anorexia and total cholesterol were less chance to adhere to the program. The other variables were not associated with dropout.

Table 1. Descriptive table of the baseline age, anthropometric, blood variables, physical fitness, psychological and quality of life in obese adolescents

\begin{tabular}{|c|c|c|c|}
\hline Variables & $\begin{array}{l}\text { Adherence } \\
\text { Mean (SD) }\end{array}$ & $\begin{array}{c}\text { Dropout } \\
\text { Mean (SD) }\end{array}$ & p value \\
\hline Age (years) & $15.2(1.57)$ & $15.9(1.72)$ & 0.01 \\
\hline Height (m) & $1.65(0.07)$ & $1.63(0.08)$ & 0.21 \\
\hline Weight (kg) & $95.2(12.4)$ & $92.5(12.7)$ & 0.20 \\
\hline BMI $\left(\mathrm{kg} / \mathrm{m}^{2}\right)$ & $34.8(4.0)$ & $34.5(4.0)$ & 0.70 \\
\hline Fat mass $(\%)$ & $51.3(11.0)$ & $53.0(6.9)$ & 0.23 \\
\hline Fat mass $(\mathrm{kg})$ & $48.7(13.4)$ & $49.7(10.0)$ & 0.62 \\
\hline Fat free mass (kg) & $45.9(10.9)$ & $43.7(8.4)$ & 0.18 \\
\hline Total cholesterol (mg/dL) & $167.3(32.2)$ & $172.8(38.1)$ & 0.36 \\
\hline LDL (mg/dL) & $106.1(28.8)$ & $106.2(32.0)$ & 0.99 \\
\hline Triglycerides (mg/dL) & $117.7(68.2)$ & $112.2(57.2)$ & 0.63 \\
\hline $\operatorname{VLDL}(\mathrm{mg} / \mathrm{dL})$ & $21.0(12.8)$ & $20.9(8.8)$ & 0.97 \\
\hline Glucose (mg/dL) & $83.8(11.9)$ & $83.4(9.5)$ & 0.86 \\
\hline $\mathrm{HDL}(\mathrm{mg} / \mathrm{dL})$ & $49.0(9.3)$ & $52.0(69.9)$ & 0.22 \\
\hline Peak VO $(\mathrm{mL} / \mathrm{kg} / \mathrm{min})$ & $25.7(4.4)$ & $26.6(5.4)$ & 0.39 \\
\hline Anorexic symptoms & $19.2(8.9)$ & $21.9(10.9)$ & 0.15 \\
\hline Trait anxiety & $45.6(10.0)$ & $45.1(12.0)$ & 0.78 \\
\hline Depression & $17.3(8.8)$ & $17.8(9.1)$ & 0.77 \\
\hline State-anxiety & $40.7(9.8)$ & $41.9(10.5)$ & 0.64 \\
\hline Binge & $13.7(7.6)$ & $14.5(8.9)$ & 0.59 \\
\hline Bulimia symptoms & $13.5(5.3)$ & $15.4(6.6)$ & 0.09 \\
\hline Bulimia severity & $2.2(2.5)$ & $2.5(3.2)$ & 0.57 \\
\hline Body dissatisfaction & $119.1(32.1)$ & $121.9(37.4)$ & 0.59 \\
\hline Physical functioning & $71.1(21.8)$ & $71.7(23.0)$ & 0.89 \\
\hline Physical role & $72.0(30.1)$ & $77.0(29.9)$ & 0.41 \\
\hline Pain & $72.5(22.1)$ & $70.4(19.9)$ & 0.63 \\
\hline General health perception & $60.8(23.7)$ & $57.4(22.5)$ & 0.47 \\
\hline Vitality & $60.1(21.6)$ & $62.3(23.9)$ & 0.61 \\
\hline Social functioning & $78.7(21.6)$ & $76.3(26.5)$ & 0.59 \\
\hline Emotional role & $68.9(35.2)$ & $74.4(35.8)$ & 0.44 \\
\hline Mental health & $70.6(22.7)$ & $72.6(23.6)$ & 0.66 \\
\hline Mean of dimensions & $69.5(17.1)$ & $70.7(17.9)$ & 0.72 \\
\hline
\end{tabular}

Independent Student's $t$ test. SD: standard deviation; BMI: body mass index; LDL: low density lipoprotein; VLDL: very low density lipoprotein; $\mathrm{HDL}$ : high density lipoprotein; peak $\mathrm{VO}_{2}$ : peak oxygen consumption.
Table 2. Crude analysis of factors associated with dropout in a multidisciplinary program for the treatment of obesity in adolescents

\begin{tabular}{|c|c|c|c|}
\hline Variables* & Odds ratio & p value & $95 \% \mathrm{CI}$ \\
\hline Sex & 0.78 & 0.48 & $0.40-1.54$ \\
\hline Shift & 1.31 & 0.45 & $0.64-2.68$ \\
\hline Age (years) & 0.48 & $<0.01$ & $0.24-0.97$ \\
\hline Anorexic symptoms & 0.50 & 0.09 & $0.22-1.13$ \\
\hline Peak $\mathrm{VO}_{2}(\mathrm{~mL} / \mathrm{kg} / \mathrm{min})$ & 1.25 & 0.54 & $0.60-2.56$ \\
\hline Bulimia symptoms & 0.82 & 0.63 & $0.37-1.82$ \\
\hline Binge & 0.97 & 0.94 & $0.44-2.14$ \\
\hline Body dissatisfaction & 1.00 & 1.00 & $0.45-2.21$ \\
\hline Bulimia severity & 0.60 & 0.21 & $0.27-1.33$ \\
\hline Trait-anxiety & 1.21 & 0.63 & $0.55-2.69$ \\
\hline State-anxiety & 0.79 & 0.66 & $0.28-2.55$ \\
\hline Depression & 0.83 & 0.63 & $0.37-1.82$ \\
\hline Total cholesterol (mg/dL) & 0.58 & 0.12 & $0.28-1.17$ \\
\hline $\mathrm{HDL}(\mathrm{mg} / \mathrm{dL})$ & 0.88 & 0.72 & $0.44-1.77$ \\
\hline $\mathrm{LDL}(\mathrm{mg} / \mathrm{dL})$ & 0.94 & 0.88 & $0.44-2.03$ \\
\hline VLD-L (mg/dL) & 0.58 & 0.25 & $0.23-1.47$ \\
\hline Glucose (mg/dL) & 0.95 & 0.89 & $0.48-1.90$ \\
\hline Triglycerides (mg/dL) & 0.81 & 0.55 & $0.40-1.64$ \\
\hline Physical functioning & 0.59 & 0.19 & $0.26-1.30$ \\
\hline Physical role & 1.23 & 0.61 & $0.55-2.74$ \\
\hline Pain & 1.54 & 0.28 & $0.69-3.46$ \\
\hline General health perception & 1.46 & 0.35 & $0.66-3.23$ \\
\hline Vitality & 0.73 & 0.44 & $0.33-1.63$ \\
\hline Social functioning & 0.84 & 0.66 & $0.38-1.86$ \\
\hline Emotional role & 0.53 & 0.12 & $0.23-1.19$ \\
\hline Mental health & 1.03 & 0.94 & $0.47-2.27$ \\
\hline
\end{tabular}

Binary logistic regression. ${ }^{*}$ The categories of reference were always below the 50th percentile, sex = male, shift = morning, age: $<15$ years. $95 \% \mathrm{Cl}$ : $95 \%$ confidence interval; peak $\mathrm{VO}_{2}$ = peak oxygen consumption; $\mathrm{HDL}$ : high density lipoprotein; LDL: low density lipoprotein; VLD-L: very low density lipoprotein.

Table 3. Adjusted analysis of factors associated with dropout in a multidisciplinary program for the treatment of obesity in adolescents

\begin{tabular}{|c|c|c|c|}
\hline Variables* & Odds ratio & $p$ value & $95 \% \mathrm{CI}$ \\
\hline Age (years) & 0.40 & 0.05 & $0.15-0.98$ \\
\hline Anorexic symptoms & 0.35 & 0.02 & $0.14-0.86$ \\
\hline Total cholesterol (mg/dl) & 0.40 & 0.05 & $0.16-0.91$ \\
\hline Physical functioning & 0.67 & 0.41 & $0.26-1.73$ \\
\hline Emotional role & 0.47 & 0.13 & $0.18-1.26$ \\
\hline
\end{tabular}

\section{DISCUSSION}

The main findings of this study were: adherence of $73.2 \%$ and lower chance of treatment adherence in adolescents aged over 15 years, with higher scores for symptoms of anorexia and total cholesterol. 
Studies relating adherence to behavior changes showed that 60 to $80 \%$ of individuals reached the minimum percentage of prescribed sessions, and about half of the participants dropped out in the first 6 months of treatment, even before the health benefits of treatment are observed. ${ }^{(9)}$ The estimated proportion of individuals that drop out from programs including exercise and changes in lifestyle is approximately $50 \% .^{(4,18)}$ However, studies have not used multidisciplinary approaches and supervised exercises, ${ }^{(7)}$ and this may explain the greater adherence observed in the present study. Furthermore, it is believed that the short duration of the intervention (12 weeks), may have contributed to this increased adherence to treatment. The different populations studied (elderly, individuals with chronic diseases, adults) and the methodology used in the studies limit comparisons of results.

The literature suggests that patients with chronic diseases, which includes obesity, have lower adherence to treatment, since the therapies, often complex, require some dedication and the patient should be followed up continuously. ${ }^{(19)}$ A study examined for 2 consecutive years the follow-up of obese children and adolescents in specialized clinics, which provide medical, nutritional, psychological and physical evaluations, and found that patient return visits gradually decreased, and $43 \%$ of them dropped out. ${ }^{(20)}$

The therapies that aim to change behavior provide patients with cognitive and behavioral skills to modify the lifestyle, helping people realize that adopting an active lifestyle and healthy life is a positive opportunity for a new life, beyond weight control in the lon0g term. ${ }^{(12)}$ However, behavioral changes related to the nutritional aspect, which is also part of the multidisciplinary program of this study, seems difficult to achieve, since some studies showed low rates of adherence to treatments with nutritional interventions. ${ }^{(21,22)}$ Independent of the type of nutrition counseling proposed (individual or group), the change in eating habits is still unsatisfactory, and studies that assess adherence to this type of treatment should be performed to constantly improve care of chronic disease patients. ${ }^{(21)}$

Our data demonstrates that higher scores of anorexia symptoms are inversely associated with compliance in a program to treat obesity, thus showing the importance of including psychological assessments in obese individuals prior to treatment. The literature suggests that individuals with symptoms of anorexia and receiving behavioral therapy, which was also used in this study, are more likely to drop out treatment than those receiving non-specific approaches. ${ }^{(23)}$ Moreover, the literature indicates that individuals with severe anorexic symptoms present problems to recover adipose tissue. ${ }^{(24,25)}$ We believe that this may hinder the perception of changes in the body, leading to demotivation and, consequently, treatment dropout.

The literature shows some variables that are associated with dropout in programs aiming at weight loss. These variables include not very realistic expectations, which are associated to greater disappointment and, consequently, treatment dropout, ${ }^{(12)}$ females; individuals with a higher BMI; those who reported previous attempts at weight loss; and younger age groups. ${ }^{(26)}$ In relation to age, the literature indicates a negative relation with physical exercise and healthy habits. ${ }^{(27)}$ In the present study, we observed that older adolescents are more likely to drop out treatment as compared to younger ones. It is common for parents of younger adolescents to accompany them to the intervention, decreasing the chance of dropping out. This hypothesis is based on the Theory of Social Control, which states that when adolescents are close to their parents, they tend to behave to please the adults. ${ }^{(28)}$

This study found no association between adherence and anthropometric indicators, unlike the study TIGER (Training Interventions and Genetics of Exercise Response), which identified that individuals with lower values of body mass, waist circumference, hip and BMI, adhered more to the aerobic exercise program. ${ }^{(29)}$ The difference between the results may be due to the type of study, beyond the age investigated, since the TIGER is an epidemiological study of adults (18 to 35 years). The present study addressed adolescents, and homogeneity of the participants' characteristics is an important factor to be considered. This study found an association between adherence and high levels of cholesterol; nonetheless, further studies are required to prove this hypothesis, since the literature has not demonstrated yet a plausible relation. Studies that investigate variables associated with biological motivation for adherence are still very scarce, ${ }^{(9)}$ thus preventing comparison of the results. We also emphasize the importance of further studies in this area, because most adolescents that should be treated to reduce lipid levels were precisely those who did not complete the intervention. The present study has some limitations, including the use of self-reported questionnaires, which may have compromised veracity due to recall bias in some cases, and, as the subjects were volunteers, only those who were willing to participate engaged in the 
intervention. The absence of family history data should be considered in the interpretation of the present data. Moreover, because it is a cross-sectional study it was not possible to establish a cause and effect relation between variables.

Finally, we verified that no single variable is able to explain and/or predict dropout in treatment programs for obesity, confirming the continuing need to investigate how the independent effects and interrelations between biological, psychological and environmental factors may influence adherence. ${ }^{(30)}$ In order to increase compliance in multidisciplinary programs for obesity treatment, a better understanding of predisposing healthy or risk behaviors, resulting from interaction of biological, psychological, environmental and genetic factors is needed. ${ }^{(9)}$

\section{CONCLUSION}

The results of this study provided evidence that older adolescents, with more symptoms of eating disorders and total cholesterol have less chance to adhere to multidisciplinary treatments weight loss.

\section{REFERENCES}

1. Bocca G, Corpeleijn E, Stolk RP, Sauer PJ. Results of a multidisciplinary treatment program in 3-year-old to 5-year-old overweight or obese children: a randomized controlled clinical trial. Arch Pediatr Adolesc Med. 2012;166(12): 1109-15.

2. Snethen JA, Broome ME, Cashin SE. Effective weight loss for overweight children: a meta-analysis of intervention studies. J Pediatr Nurs. 2006;21(1): $45-56$.

3. van der Baan-Slootweg 0, Benninga MA, Beelen A, van der Palen J, Tamminga-Smeulders C, Tijssen JG, et al. Inpatient treatment of children and adolescents with severe obesity in the Netherlands: a randomized clinical trial. JAMA Pediatr. 2014;168(9):807-14.

4. Fuster V. [An alarming threat to secondary prevention: low compliance (lifestyle) and poor adherence (drugs)]. Rev Esp Cardiol (Engl Ed). 2012;65 Suppl 2:10-6. Review. Spanish.

5. Alberga AS, Medd ER, Adamo KB, Goldfield GS, Prud'homme D, Kenny GP, et al. Top 10 practical lessons learned from physical activity interventions in overweight and obese children and adolescents. Appl Physiol Nutr Metab. 2013;38(3):249-58.

6. Zeller M, Kirk S, Claytor R, Khoury P, Grieme J, Santangelo M, et al. Predictors of attrition from a pediatric weight management program. J Pediatr. 2004; 144(4):466-70.

7. van den Akker EL, Puiman PJ, Groen M, Timman R, Jongejan MT, Trijsburg W. A cognitive behavioral therapy program for overweight children. J Pediatr. 2007;151(3):280-3.

8. Lofrano-Prado MC, HILL JO, Silva HJ, Freitas CR, Freitas CM, Ferreira MN, et al. Reasons and barriers to lose weight: obese adolescents point of view. $\mathrm{Br}$ J Med Med Res. 2013;3(3):474-82.

9. Herring MP, Sailors MH, Bray MS. Genetic factors in exercise adoption, adherence and obesity. Obes Rev. 2014;15(1):29-39. Review.
10. Rivera JÁ, de Cossío TG, Pedraza LS, Aburto TC, Sánchez TG, Martorell R. Childhood and adolescent overweight and obesity in Latin America: a systematic review. Lancet Diabetes Endocrinol. 2014;2(4):321-32. Review.

11. Saydah S, Bullard KM, Cheng Y, Ali MK, Gregg EW, Geiss L, et al. Trends in cardiovascular disease risk factors by obesity level in adults in the United States, NHANES 1999-2010. Obesity (Silver Spring). 2014;22(8):1888-95.

12. Dalle Grave R, Calugi S, Centis E, El Ghoch M, Marchesini G. Cognitive-behavioral strategies to increase the adherence to exercise in the management of obesity. J Obes. 2011;2011:348293.

13. Moroshko I, Brennan L, O'Brien P. Predictors of dropout in weight loss interventions: a systematic review of the literature. Obes Rev. 2011;12(11): 912-34. Review.

14. Tanner JM, Whitehouse RH. Clinical Longitudinal standards for height, weight, height velocity, weight velocity and stages of puberty. Arch Dis Child. 1976;51(3):170-9. Review.

15. Dâmaso AR, da Silveira Campos RM, Caranti DA, de Piano A, Fisberg M, Foschini $D$, et al. Aerobic plus resistance training was more effective in improving the visceral adiposity, metabolic profile and inflammatory markers than aerobic training in obese adolescents. J Sports Sci. 2014;32(15):1435-45.

16. Farah B0, Ritti-Dias RM, Balagopal PB, Hill J0, Prado WL. Does exercise intensity affect blood pressure and heart rate in obese adolescents? A 6-month multidisciplinary randomized intervention study. Pediatr Obes. 2014; $9(2): 111-20$.

17. Slaughter MH, Lohman TG, Boileau RA, Horswill CA, Stillman RJ, Van Loan MD, et al. Skinfold equations for estimation of body fatness in children and youth. Hum Biol. 1988;60(5):709-23.

18. Medina-Mirapeix F, Escolar-Reina P, Gascón-Cánovas JJ, Montilla-Herrador J. Coliins SM. Personal characteristics influencing patients' adherence to home exercise during chronic pain: a qualitative study. J Rehabil Med. 2009; 41(5):347-52.

19. Reppold CT, Poersch AL, Mazoni CG. Aspectos psicológicos e adesão ao tratamento. In: Gottschall CB, Busnello FM. Nutrição e síndrome metabólica. São Paulo: Atheneu; 2009. p. 273-81.

20. Zambon MP, Antonio MA, Mendes RT, Barros Filho AA. Obese children and adolescents: two years of interdisciplinary follow-up. Rev Paul Pediatr. 2008;26(2):130-5. Portuguese.

21. Guimarães NG, Dutra ES, Ito MK, Carvalho KM. Adesão a um programa de aconselhamento nutricional para adultos com excesso de peso e comorbidades. Rev Nutr. 2010;23(3):323-33.

22. Corica F, Corsonello A, Apolone G, Mannucci E, Lucchetti M, Bonfiglio C, et al. Metabolic syndrome, psychological status and quality of life in obesity: the QUOVADIS Study. Int J Obes (Lond). 2008;32(1):185-91.

23. Vandereycken W, Pierloot R. Drop-out during in-patient treatment of anorexia nervosa: a clinical study of 133 patients. Br J Med Psychol. 1983;56(Pt 2):145-56.

24. Mayer L, Walsh BT, Pierson RN Jr, Heymsfield SB, Gallagher D, Wang J, et al. Body fat redistribution after weight gain in women with anorexia nervosa. Am J Clin Nutr. 2005;81(6):1286-91.

25. Grinspoon S, Thomas L, Miller K, Pitts S, Herzog D, Klibanski A. Changes in regional fat redistribution and the effects of estrogen during spontaneous weight gain in women with anorexia nervosa. Am J Clin Nutr. 2001;73(5): 865-9.

26. Bautista-Castaño I, Molina-Cabrillana J, Montoya-Alonso JA, Serra-Majem L. Variables predictive of adherence to diet and physical activity recommendations in the treatment of obesity and overweight, in a group of Spanish subjects. Int J Obes Relat Metab Disord. 2004;28(5):697-705.

27. Seabra AF, Mendonça DM, Thomis MA, Malina RM, Maia JA. Correlates of physical activity in Portuguese adolescents from 10 to 18 years. Scand J Med Sci Sports. 2011;21(2):318-23.

28. Wright JP, Cullen FT. Parental efficacy and delinquent behavior: do control and support matter? Criminology. 2001;39(3):677-706. 
29. Sailors MH, Jackson AS, McFarlin BK, Turpin I, Ellis KJ, Foreyt JP, et al. Exposing college students to exercise: the Training Interventions and Genetics of Exercise Response (TIGER) study. J Am Coll Health. 2010;59(1):13-20.
30. McBride CM, Bryan AD, Bray MS, Swan GE, Green ED. Health behavior change: can genomics improve behavioral adherence? Am J Public Health. 2012;102(3):401-5. 